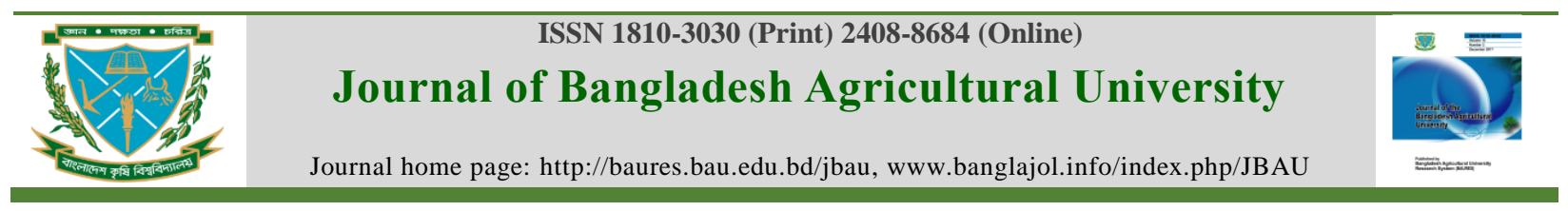

\title{
Effect of weeding regime on the performance of boro rice cultivars
}

\author{
Rakia Afroz, Md. Abdus Salam ${ }^{\varpi}$, Mahfuza Begum \\ Department of Agronomy, Bangladesh Agricultural University, Mymesningh 2202, Bangladesh
}

\begin{tabular}{|c|c|}
\hline ARTICLE INFO & AbStract \\
\hline $\begin{array}{l}\text { Article history: } \\
\text { Received : } 26 \text { December } 2018 \\
\text { Accepted : } 01 \text { April } 2019 \\
\text { Published: } 30 \text { September } 2019\end{array}$ & \multirow{4}{*}{$\begin{array}{l}\text { An experiment was conducted at the Agronomy Field Laboratory, Bangladesh Agricultural University } \\
\text { Mymensingh from December } 2016 \text { to May } 2017 \text { to investigate the effect of weeding regime on the } \\
\text { performance of boro rice cultivars. The experiment comprised of two factors, Factor A- Rice cultivars } \\
\text { BRRI dhan } 28 \text {, BRRI dhan } 29 \text {, and BRRI dhan } 74 \text {, Factor B: Methods of weeding- no weeding, two han } \\
\text { weedings at } 15 \text { and } 35 \text { DATs, application of pre-emergence herbicide Commit, application of early post } \\
\text { emergence herbicide Pediplus, application of pre-emergence herbicide Commit followed by application } \\
\text { of early post-emergence herbicide Pediplus, application of pre-emergence herbicide Commit followec } \\
\text { by one hand weeding at } 35 \text { DAT, and application of early post-emergence herbicide Pediplus followec } \\
\text { by one hand weeding at } 35 \text { DAT. The experiment was laid out in a split plot design assigning rice } \\
\text { cultivars in the main plots and weed management practices in the sub-plots with three replications } \\
\text { Fourteen weed species infested the experimental field belonging to six families. Among the weec } \\
\text { species, four were grasses, four were broad leaves and six were sedges. Cultivar exerted significan } \\
\text { effect on weed density and dry weight. Both the highest weed density and dry weight were found in } \\
\text { BRRI dhan } 28 \text { and the lowest ones were observed in BRRI dhan } 29 \text { rice cultivar. Weed density and weec } \\
\text { dry weight were significantly influenced by weeding regime. The highest weed density and dry weigh } \\
\text { were observed in no weeding condition and application of pre-emergence herbicide Commit followec } \\
\text { by one hand weeding at } 35 \text { DAT showed the best performance. BRRI dhan } 29 \text { produced the highest grair } \\
\text { and straw yields among the cultivars. Weed control had pronounced influence on yield of rice. The } \\
\text { highest grain yield was obtained in application of pre-emergence herbicide Pretilachlo } \\
\text { (Commit)followed by one hand weeding at } 35 \text { DAT and the lowest one was obtained in control (no } \\
\text { weeding) treatment. From the results of the study it may be concluded that rice cultivar BRRI dhan2 } \\
\text { with application of pre-emergence herbicide Commit followed by one hand weeding at } 35 \text { DAT migh } \\
\text { be the best treatment for controlling weed effectively as well as obtaining highest yield and highes } \\
\text { economic return. }\end{array}$} \\
\hline $\begin{array}{l}\text { Keywords: } \\
\text { Boro rice, } \\
\text { Pre-emergence herbicide, } \\
\text { Early post emergence herbicide, } \\
\text { weeding regime, } \\
\text { yield }\end{array}$ & \\
\hline $\begin{array}{l}\text { Correspondence: } \\
\text { Md Abdus Salam } \\
\bigotimes: \text { salamma71@yahoo.com }\end{array}$ & \\
\hline & \\
\hline
\end{tabular}

Copyright $\odot 2019$ by authors and BAURES. This work is licensed under the Creative Commons Attribution International License (CC By 4.0).

\section{Introduction}

Rice (Oryza sativa L.) is the dominant food crop of Bangladesh. The area and production of boro rice in the country were 4.44 million hectares and 18.01 million tons, respectively in 2016-2017 with the yield of $4.05 \mathrm{t}$ $\mathrm{ha}^{-1}$ (BBS, 2018). The output of boro rice, which accounts for $55 \%$ of the total annual rice production, fell by $1.32 \%$ from a year earlier to 189.38 lakh tons during the production of fiscal year 2015-16, according to preliminary estimate of BBS (2016). Bangladesh is the fourth largest rice producer in the world but its productivity is low compared to other Asian countries. The average yield of rice is almost less than $50 \%$ of the world average rice grain yield. The increasing rate of population is $1.05 \%$ (BBS, 2018) and decreasing rate of agricultural land is by $1 \%$ per annum (Hussain et al., 2006) which limits the horizontal expansion of rice area. So, rice yield should be increased to meet this ever increasing demand of food. To overcome the situation, increment of rice production per unit area is only the alternative to bring self-sufficiency in food production.

Infestation of weed is one of the most important causes for low yield of rice. There is no doubt that maximum benefit from costly inputs like fertilizers and pesticides in rice can fully be derived when the crop is kept free from weed infestation. Production cost of rice increases due to increase in weed control cost. The present weed management system which is done manually is laborious, time consuming, expensive and cannot be done in time due to various reasons (Ahmed et al., 2005). Labour availability in agricultural operations has decreased in

Cite this article

Afroz, R., Salam, M.A. and Begum, M. 2019. Effect of weeding regime on the performance of boro rice cultivars. Journal of Bangladesh Agricultural University, 17(3): 265-273. https://doi.org/10.3329/jbau.v17i3.43192 
recent years due to migration of landless people towards the urban areas with a dream to earn more.

Rice cultivars have tremendous impact on the growth and infestation of weed in the field. Usually short stature cultivars face more weed infestation than the taller ones (Sarker, 1979). So, to avoid the weed competition and to get maximum yield from rice, appropriate cultivar should be selected. Again, herbicides are effective in controlling weeds alone or in combination with hand weeding (Ahmed et al., 2005). Herbicides in combination with hand weeding would help to obtain higher crop yield with less efforts and cost (Prasad and Rafy, 1995; Sathyamoorthy et al., 2004). Weed competition at early growth stage can be eliminated through application of herbicide. Replacement of traditional weeding in Boro rice by pre-emergence herbicide and early postemergence herbicide or herbicides in combination with hand weeding would help to obtain higher crop yield. Therefore, the best weed control method needs to be found out with a view to reducing losses due to weed infestation and thus getting maximum yield. A few research works on the productivity of Boro rice and weed growth due to cultivar and weeding regimes have been done in Bangladesh. The present research work was, therefore, undertaken to evaluate the effect of cultivars on weed growth and yield performance of Boro rice, to assess the effect of weeding regime on weed growth and yield of Boro rice, to see the interaction effect of cultivar and weeding regime on weed growth and yield of Boro rice. Economics of different weeding regimes were also evaluated.

\section{Materials and Methods}

\section{Experimental site}

The experiment was conducted at the Agronomy Field Laboratory, Bangladesh Agricultural University, Mymensingh during December 2016 to May 2017 to study the effect of cultivar and weeding regime on weed growth and the performance of Boro rice. The experimental site belongs to the non-calcareous dark grey floodplain soil under the Agro-ecological Zone of the Old Brahmaputra Floodplain (AEZ-9) (FAO and UNDP, 1988). The soil of the experimental field was more or less neutral in reaction with $\mathrm{pH} 6.5$, low in organic matter and fertility level. The land type was medium high with silt loam in texture.

\section{Treatments and design}

The experiment consists of two factors, Factor A: Rice cultivars- BRRI dhan28 ( $\left.\mathrm{V}_{1}\right)$, BRRI dhan29 $\left(\mathrm{V}_{2}\right)$, and BRRI dhan74 $\left(\mathrm{V}_{3}\right)$, Factor B: Methods of weeding- No weeding $\left(\mathrm{W}_{0}\right)$, Two hand weedings at 15 and 35 DATs $\left(\mathrm{W}_{1}\right)$, application of pre-emergence herbicide (Pretilchlor)@ $\left.2 \mathrm{~L} \mathrm{ha}^{-1}\right)\left(\mathrm{W}_{2}\right)$, application of early postemergence herbicide Pediplus (Acetachlor +Bensufuron methyl)@750 $\left.\mathrm{g} \mathrm{ha}^{-1}\right)\left(\mathrm{W}_{3}\right)$, application of pre-emergence herbicide (Pretilchlor) followed by early post-emergence herbicide (Acetachlor +Bensufuron methyl) $\left(\mathrm{W}_{4}\right)$, application of pre-emergence herbicide (Pretilchlor) followed by one hand weeding at 35 DAT $\left(\mathrm{W}_{5}\right)$ and application of early post-emergence herbicide (Acetachlor + Bensufuron methyl) followed by one hand weeding at 35 DAT $\left(\mathrm{W}_{6}\right)$. The experiment was laid out in a split plot design assigning cultivars in the main plot and weed management practices in the sub-plots with three replications.

In no weeding treatment weeds were allowed to grow up to harvesting of the crop. In two hand weedings treatment, weeds were allowed to grow with the first 15 DAT. At 15 days one hand weeding was done. Weeds were allowed to grow with the crop till 35 DAT and then another hand weeding was given and afterwards no weeding was done till harvesting. In application of pre-emergence herbicide treatment, Pretilachlor@ $2 \mathrm{~L} \mathrm{ha}^{-1}$ was applied at 4 DAT in 4 to $5 \mathrm{~cm}$ standing water by hand sprayer in the plots and no weeding was done till harvesting. In Application of early post-emergence herbicide treatment, Pediplus 18WP (Acetachlor + Bensufuron methyl) @ $750 \mathrm{~g} \mathrm{ha}^{-1}$ mixed with urea and was applied at 12 DAT in $4-5 \mathrm{~cm}$ standing water in the plots and no weeding was done till harvesting. In application of pre-emergence herbicide followed by early post-emergence herbicide, pre emergence herbicide (Pretilachlor) was applied at 4 DAT and early post emergence herbicide Pediplus 18WP (Acetachlor + Bensufuron methyl) @750 g ha-1 mixed with urea was applied at 12 DAT in 4 to $5 \mathrm{~cm}$ standing water by hand sprayer in the plots and no weeding was done till harvesting. In application of pre-emergence herbicide followed by one hand weeding at 35 DAT, preemergence herbicide Pretilachlor @ $2 \mathrm{~L} \mathrm{ha}^{-1}$ was applied at 4 DAT in 4 to $5 \mathrm{~cm}$ standing water by hand sprayer in the plots and at 35 days one hand weeding was done. In case of application of early post-emergence herbicide followed by one hand weeding at 35 DAT treatment, Pediplus 18WP (Acetachlor + Bensufuron methyl) @ $750 \mathrm{gha}^{-1}$ mixed with urea was applied at 12 DAT in 4-5 $\mathrm{cm}$ standing water in the plots and at 35 days one hand weeding was done.

\section{Agronomic management}

Seeds of rice variety BRRI dhan28, BRRI dhan29 and BRRI dhan74 were collected from Bangladesh Rice Research Institute, Joydebpur, Gazipur. The sprouted seeds were sown in the nursery bed on 20 November 2016. Proper care was taken to raise the healthy seedlings in the nursery bed. Weeds were removed and irrigation was given in the nursery bed as and when necessary. After laying out the land fertilized with urea, triple super phosphate, gypsum and zinc sulphate@ 300-100-120$110-10 \mathrm{~kg} \mathrm{ha}^{-1}$, respectively as per recommendation of BRRI (2018). The entire amounts of TSP, MoP, gypsum and zinc sulphate were applied at the time of final land preparation. Urea was applied in three equal instalments at 15, 30 and 45 days after transplanting. Seedlings were 
transplanted in the well prepared puddle field on 3 January 2017 @ two seedlings hill ${ }^{-1}$, maintaining row and hill distances of $25 \mathrm{~cm}$ and $15 \mathrm{~cm}$, respectively. The experimental plots were irrigated as and when necessary. At the time when $80 \%$ of the panicles turned into golden yellow color, the crop was assessed to attain maturity. Rice cultivar BRRI dhan28 was harvested on 30 April 2017. BRRI dhan29 and BRRI dhan 74 were harvested on 04 May 2017. Five hills (excluding border rows and central $1.0 \mathrm{~m} \times 1.0 \mathrm{~m}$ area) were selected randomly from each unit plot and uprooted before harvesting for recording the data of yield and yield attributes of rice. After sampling a harvest area of central $1 \mathrm{~m} \times 1 \mathrm{~m}$ was selected from each unit plot. Then the harvested crops of each plot was bundled separately and properly tagged and brought to the threshing floor. Grains were separated from the plants by pedal thresher. The collected grains and straw were cleaned and weighed. The moisture content of the collected grains was measured by grain moisture meter. Then the grain moisture content was adjusted to $14 \%$ moisture content. Finally grain and straw yields per unit area were converted to $\mathrm{tha}^{-1}$. Weed density and dry weight were recorded for weed growth data. Weeds were collected from three spots of each plot at 20, 40 DAT, 60 DAT and 80 DAT of the rice plants by using a $0.25 \mathrm{~m} \times$ $0.25 \mathrm{~m}$ quadrate as per described by Cruz et al. (1986). The weeds within the quadrate were counted and converted to number $\mathrm{m}^{-2}$ multiplying by four. At 20, 40, 60 and 80 DAT weeds $\mathrm{m}^{-2}$ area was uprooted from all individual plots, soil from roots was cleared and the weed plant was oven dried for 72 hours at a temperature of $80^{\circ} \mathrm{C}$ until constant weight was reached.

\section{Statistical analysis}

Data were compiled and tabulated in proper form for statistical analysis. The recorded data were statistically analyzed to find out the significance of variation resulting from the experimental treatments. All the collected data were analyzed following the analysis of variance (ANOVA) technique and mean differences were adjudged by Duncan's Multiple Range Test (DMRT) (Gomez and Gomez, 1984) using a computer operated program MSTAT-C.

\section{Results and Discussion}

\section{Infested weed species in the experimental field}

Fourteen weed species infested the experimental field belonging to six families. Among the weed species four were grasses, four were broad leaves and six were sedges. Local name, scientific name, family, morphological type and life cycle of the weed in the experimental plots are presented in Table 1. The common weeds of the experimental plots were Paspalum scrobiculatum, Echinochloa crusgalli, Leersia hexandra, Oxalis europea, Monochoria vaginalis, Ludwigia hyssopifolia, Cyperus difformis and Scirpus juncoides. Bari et al. (1995) reported that in BAU farm the major weeds of Boro rice fields were Fimbristylis miliacea, Paspalum scrobiculatum and Cyperus rotundus. But from the same location Mamun et al. (1993) reported that Fimbristylis miliacea, Lindernia antipola and Eriocaulen cenerseem were the important weeds in transplanted Boro rice field.

\section{Effect of cultivar on weed density and dry weight}

Weed density and dry weight at 20, 40, 60 and 80 days after transplanting (DAT) were significantly affected by cultivar (Figure 1 and Figure 3). Over the cropping season, the highest weed density and dry weight were recorded in BRRI dhan 28 and the lowest ones were observed in BRRI dhan29 (Figure 1 and Figure 3). This study shows that the highest weed density was found with the dwarf cultivar BRRI dhan28 and the lowest one with the tallest cultivar BRRI dhan29. The observation is in agreement with the finding of Sarker (1979) who reported that the tall cultivar produced lower weed density and lower weed dry weight than the dwarf cultivar.

Table 1. Infesting weed species found growing in the experimental plots of Boro rice

\begin{tabular}{|c|c|c|c|c|c|}
\hline $\begin{array}{l}\text { SI. } \\
\text { No. }\end{array}$ & Local name & Scientific name & Family & Morphology & Life cycle \\
\hline 1. & Shama & Echinochloa crusgalli (L.) P. Beauv. & Poaceae & Grass & Annual \\
\hline 2. & Angta & Paspalum scrobiculatum $\mathrm{L}$. & Poaceae & Grass & Perennial \\
\hline 3. & Arail & Leersia hexandra Swartz & Poaceae & Grass & Annual \\
\hline 4. & SabujNakful & Cyperus difformis $\mathrm{L}$. & Cyperaceae & Sedge & Annual \\
\hline 5. & Pani chaise & Eleocharis atropurpurea (Retz.) J.Presl \& C. Pres & Cyperaceae & Sedge & Annual \\
\hline 6. & ChotoAnguli gash & Digitaria setigera Roth & Cyperaceae & Grass & Annual \\
\hline 7. & SabujNakful & Cyperus difformis $\mathrm{L}$. & Cyperaceae & Sedge & Annual \\
\hline 8. & Joina & Fimbristylis miliacea $\mathrm{L}$. & Cyperaceae & Sedge & Annual \\
\hline 9. & Mutha & Cyperus rotundus $\mathrm{L}$. & Cyperaceae & Sedge & Perennial \\
\hline 10. & Chesra & Scirpus juncoides Roxb. & Cyperaceae & Sedge & Annual \\
\hline 11. & Amrulshak & Oxalis europea L. & Oxaledaceae & Broad leaved & Annual \\
\hline 12. & Keshuti & Eclipta alba $\mathrm{L}$ & Compositae & Broad Leaved & Annual \\
\hline 13. & Malancha & Alternathera philoxeroides $\mathrm{L}$. & Araceae & Broad leaved & Annual \\
\hline 14. & Panikachu & Monochoria vaginalis (Burm. F.) C. Presl & Pontederiaceae & Broad leaved & Annual \\
\hline
\end{tabular}


Hoque et al. (2003) and Sunyob et al. (2015) also reported that short stature plant with its erect leaf habit promoted more weed growth and caused more loss than that of tall cultivar.

\section{Effect of weeding regime on weed density and dry weight}

Weed density was significantly influenced by weeding regimes at 20, 40,60 and 80 DATs (Figure 2). At 20 DAT, the highest weed density $\left(83.55 \mathrm{~m}^{-2}\right)$ was found in $\mathrm{W}_{0}$ (No weeding) and the lowest one $\left(18.78 \mathrm{~m}^{-2}\right)$ was found in $\mathrm{W}_{5}$ (Pre-emergence herbicide Pretilachlor followed by one hand weeding at 35 DAT) treatment. At 40 DAT, the highest weed density $\left(90.67 \mathrm{~m}^{-2}\right)$ was found in $\mathrm{W}_{0}$ (No weeding) and lowest one $\left(8.44 \mathrm{~m}^{-2}\right)$ was found in $\mathrm{W}_{5}$ (Preemergence herbicide Pretilachlor followed by one hand weeding at $35 \mathrm{DAT})$. At $60 \mathrm{DAT}$, the highest weed density $\left(105.1 \mathrm{~m}^{-2}\right.$ ) was found in $\mathrm{W}_{0}$ (No weeding) and the lowest one $\left(18.22 \mathrm{~m}^{-2}\right)$ was found in $\mathrm{W}_{5}$ (Preemergence herbicide Pretilachlor followed by one hand weeding at $35 \mathrm{DAT})$. At $80 \mathrm{DAT}$, the highest weed population $\left(152.4 \mathrm{~m}^{-2}\right.$ ) was found in $\mathrm{W}_{0}$ (No weeding) and the lowest one $\left(20.45 \mathrm{~m}^{-2}\right)$ was found in $\mathrm{W}_{5}$ (Preemergence herbicide Pretilachlor followed by one hand

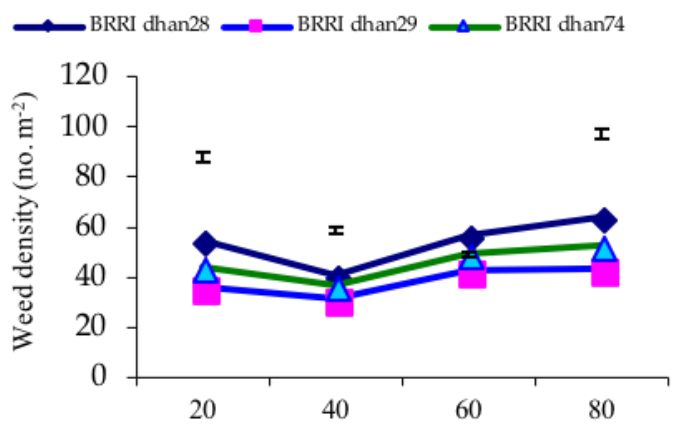

Days after transplanting

Fig.1 Effect of cultivar on weed density at 20, 40,60, and 80 DATs

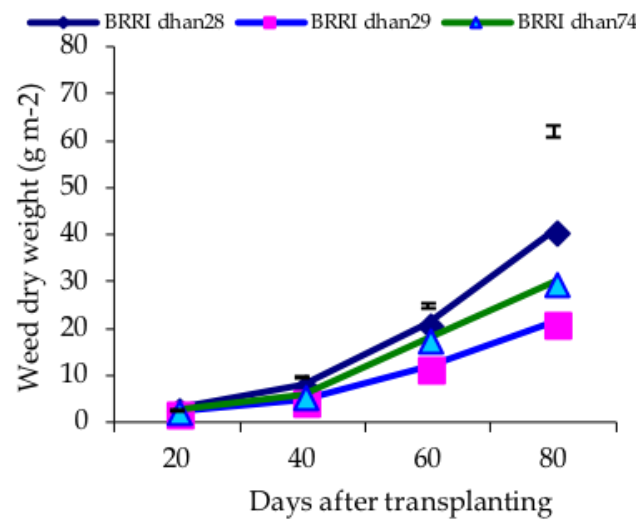

Fig.3 Effect of cultivar on weed dry weight at 20, 40, 60, and 80 DATs weeding at 35 DAT) (Figure 2). Similar trend was observed in weed dry weight at 20,40,60 and 80 DATs (Figure 4). Weed crop competition was highest in no weeding treatment and weed dry was highest in no weeding treatment at different DATs. On the other hand, application of pre-emergence herbicide Pretilachlor followed by one hand weeding at $35 \mathrm{DAT}$ controlled the weed effectively and this was the probable cause of lowest weed dry weight in this treatment.

\section{Interaction effect of cultivar and weeding regime on weed density and dry weight}

The interaction effect of cultivar and weeding regime on weed density and dry weight was found significant at 20, 40, 60 and 80 DATs (Table 2). At 20, 40, 60 and 80 DATs, the highest weed density and dry weight were recorded in BRRI dhan 28 under No weeding condition and the lowest weed density and dry weight were found in BRRI dhan29 when pre-emergence herbicide Pretilachlor followed by one hand weeding at 35 DAT were applied (Table 2).

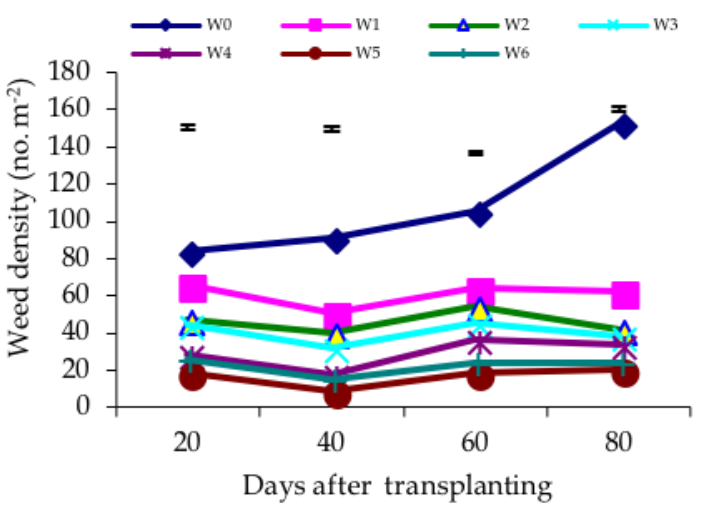

Fig. 2 Effect of weeding regimes on weed density at 20, 40, 60 , and 80 DATs

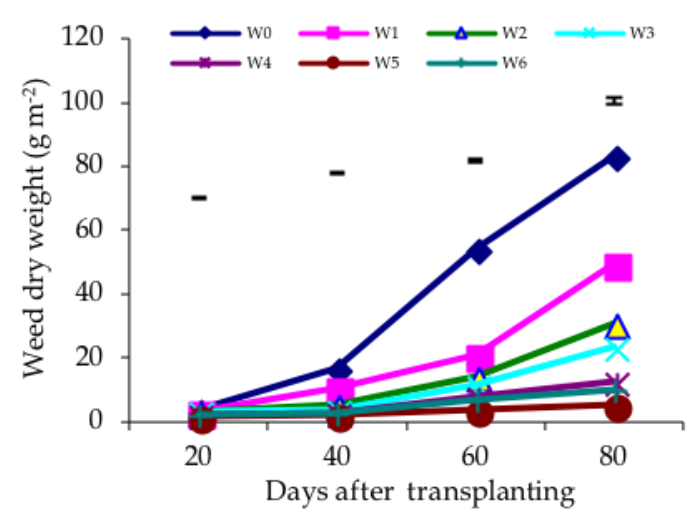

Fig. 4 Effect of weeding regimes on weed dry weight at 20, 40,60 , and 80 DATs 
Table 2. Interaction effects of cultivar and methods of weeding on weed density and weed dry weight of Boro rice at different days after transplanting

\begin{tabular}{|c|c|c|c|c|c|c|c|c|}
\hline \multirow{2}{*}{$\begin{array}{l}\text { Interaction } \\
\text { (Cultivars } \times \\
\text { weeding } \\
\text { methods) }\end{array}$} & \multicolumn{4}{|c|}{ Weed density $\left(\right.$ no. $\left.\mathrm{m}^{-2}\right)$ at different DAT } & \multicolumn{4}{|c|}{ Weed dry weight $\left(\mathrm{g} \mathrm{m}^{-2}\right)$ at different DAT } \\
\hline & 20 & 40 & 60 & 80 & 20 & 40 & 60 & 80 \\
\hline $\mathrm{V}_{1} \mathrm{~W}_{0}$ & $85.33 \mathrm{a}^{*}$ & $101.3 \mathrm{a}$ & $116.0 \mathrm{a}$ & $188.0 \mathrm{a}$ & $3.99 \mathrm{a}$ & $21.21 \mathrm{a}$ & $69.17 \mathrm{a}$ & $106.8 \mathrm{a}$ \\
\hline $\mathrm{V}_{1} \mathrm{~W}_{1}$ & $70.67 b$ & $53.33 d$ & $69.33 \mathrm{~d}$ & $72.00 \mathrm{~d}$ & $3.45 b c$ & $14.85 b c$ & $22.65 d$ & $72.91 \mathrm{c}$ \\
\hline $\mathrm{V}_{1} \mathrm{~W}_{2}$ & $68.00 \mathrm{~b}$ & $44.00 \mathrm{ef}$ & $62.67 \mathrm{e}$ & $45.33 \mathrm{~g}$ & $3.29 \mathrm{bcd}$ & 5.97e & $20.00 \mathrm{e}$ & $37.81 \mathrm{f}$ \\
\hline $\mathrm{V}_{1} \mathrm{~W}_{3}$ & $68.00 \mathrm{~b}$ & $40.00 \mathrm{f}$ & $49.33 \mathrm{~g}$ & $42.67 \mathrm{gh}$ & $3.13 \mathrm{de}$ & $5.33 \mathrm{ef}$ & $14.40 \mathrm{~g}$ & $27.64 \mathrm{gh}$ \\
\hline $\mathrm{V}_{1} \mathrm{~W}_{4}$ & $34.67 \mathrm{e}$ & $20.00 \mathrm{j}$ & $45.33 \mathrm{~h}$ & $40.00 \mathrm{~h}$ & $2.85 \mathrm{ef}$ & $3.75 \mathrm{gh}$ & $8.733 \mathrm{j}$ & $17.69 \mathrm{i}$ \\
\hline $\mathrm{V}_{1} \mathrm{~W}_{5}$ & $22.67 \mathrm{ij}$ & $9.330 \mathrm{mn}$ & $28.00 \mathrm{kl}$ & $28.00 \mathrm{j}$ & 1.87ijk & 2.81hij & $5.070 \mathrm{~lm}$ & $6.790 \mathrm{k}$ \\
\hline $\mathrm{V}_{1} \mathrm{~W}_{6}$ & $32.00 \mathrm{ef}$ & $18.67 \mathrm{j}$ & $28.00 \mathrm{kl}$ & 30.67ij & $2.71 \mathrm{fg}$ & 2.93hi & $8.080 \mathrm{jk}$ & 16.09ij \\
\hline $\mathrm{V}_{2} \mathrm{~W}_{0}$ & $81.33 \mathrm{a}$ & $78.67 \mathrm{c}$ & $91.33 \mathrm{c}$ & $128.0 \mathrm{c}$ & $3.36 \mathrm{bcd}$ & $14.0 \mathrm{c}$ & $32.31 \mathrm{c}$ & $58.87 \mathrm{~d}$ \\
\hline $\mathrm{V}_{2} \mathrm{~W}_{1}$ & $61.33 c$ & $46.67 \mathrm{e}$ & $61.33 \mathrm{e}$ & $52.00 \mathrm{f}$ & $3.17 \mathrm{~cd}$ & $6.13 \mathrm{e}$ & $17.93 \mathrm{f}$ & $31.55 \mathrm{~g}$ \\
\hline $\mathrm{V}_{2} \mathrm{~W}_{2}$ & $30.67 \mathrm{efg}$ & $36.00 \mathrm{~g}$ & $45.33 \mathrm{~h}$ & $34.67 \mathrm{i}$ & $3.12 \mathrm{de}$ & $4.68 \mathrm{fg}$ & 9.512ij & $25.99 \mathrm{~h}$ \\
\hline $\mathrm{V}_{2} \mathrm{~W}_{3}$ & $25.33 \mathrm{hi}$ & $24.00 \mathrm{i}$ & $41.33 \mathrm{i}$ & $30.67 \mathrm{ij}$ & $2.57 \mathrm{~g}$ & $3.21 \mathrm{hi}$ & $8.913 \mathrm{j}$ & $17.13 \mathrm{i}$ \\
\hline $\mathrm{V}_{2} \mathrm{~W}_{4}$ & $20.00 \mathrm{jk}$ & $16.00 \mathrm{jkl}$ & $30.67 \mathrm{jk}$ & 30.67ij & 2.00hij & $1.92 \mathrm{ij}$ & $6.413 \mathrm{kl}$ & $8.211 \mathrm{k}$ \\
\hline $\mathrm{V}_{2} \mathrm{~W}_{5}$ & $16.33 \mathrm{k}$ & $6.670 \mathrm{n}$ & $12.00 n$ & $14.67 \mathrm{k}$ & $1.67 \mathrm{k}$ & $1.56 \mathrm{j}$ & $2.130 \mathrm{n}$ & 2.1701 \\
\hline $\mathrm{V}_{2} \mathrm{~W}_{6}$ & $17.33 \mathrm{k}$ & $12.001 \mathrm{~m}$ & $16.00 \mathrm{~m}$ & $14.67 \mathrm{k}$ & 1.97hij & $1.85 \mathrm{ij}$ & 6.1281 & $7.091 \mathrm{k}$ \\
\hline $\mathrm{V}_{3} \mathrm{~W}_{0}$ & $84.00 \mathrm{a}$ & $92.00 \mathrm{~b}$ & $108.0 \mathrm{~b}$ & $141.3 b$ & $3.49 \mathrm{~b}$ & $15.63 b$ & $61.77 b$ & $84.98 b$ \\
\hline $\mathrm{V}_{3} \mathrm{~W}_{1}$ & $66.67 b$ & $52.00 \mathrm{~d}$ & $62.00 \mathrm{e}$ & $64.00 \mathrm{e}$ & $3.20 \mathrm{bcd}$ & $10.33 \mathrm{~d}$ & $22.05 \mathrm{~d}$ & $44.00 \mathrm{e}$ \\
\hline $\mathrm{V}_{3} \mathrm{~W}_{2}$ & $43.00 \mathrm{~d}$ & $41.33 \mathrm{f}$ & $56.00 \mathrm{f}$ & $45.33 \mathrm{~g}$ & $3.13 \mathrm{de}$ & $5.60 \mathrm{ef}$ & $12.52 \mathrm{~h}$ & $27.97 \mathrm{gh}$ \\
\hline $\mathrm{V}_{3} \mathrm{~W}_{3}$ & $41.33 d$ & $32.00 \mathrm{~h}$ & $45.33 \mathrm{~h}$ & $41.33 \mathrm{gh}$ & $3.11 \mathrm{de}$ & 3.00hi & 10.88hi & $25.84 \mathrm{~h}$ \\
\hline $\mathrm{V}_{3} \mathrm{~W}_{4}$ & $29.33 \mathrm{fgh}$ & $17.33 \mathrm{jk}$ & $33.33 \mathrm{j}$ & $32.00 \mathrm{ij}$ & $2.19 \mathrm{~h}$ & 2.85hij & $8.172 \mathrm{jk}$ & $12.41 \mathrm{j}$ \\
\hline $\mathrm{V}_{3} \mathrm{~W}_{5}$ & $17.33 \mathrm{k}$ & $9.330 \mathrm{mn}$ & $14.6 \mathrm{mn}$ & $18.67 \mathrm{k}$ & $1.77 \mathrm{jk}$ & $2.23 \mathrm{ij}$ & $3.677 \mathrm{mn}$ & $6.750 \mathrm{k}$ \\
\hline $\mathrm{V}_{3} \mathrm{~W}_{6}$ & $26.67 \mathrm{ghi}$ & $13.33 \mathrm{klm}$ & 26.671 & $26.67 \mathrm{j}$ & $2.07 \mathrm{hi}$ & 2.68hij & $6.373 \mathrm{kl}$ & $7.211 \mathrm{k}$ \\
\hline Level of sig. & 0.01 & 0.01 & 0.01 & 0.01 & 0.01 & 0.01 & 0.01 & 0.01 \\
\hline $\mathrm{CV}(\%)$ & 5.41 & 6.51 & 3.48 & 5.44 & 5.71 & 11.28 & 5.97 & 7.86 \\
\hline
\end{tabular}

*In a column, figures with same letter (s) or without letter do not differ significantly whereas figures with dissimilar letter differ significantly (as per DMRT)

$\mathrm{V}_{1}=\mathrm{BRRI}$ dhan28, $\mathrm{V}_{2}=\mathrm{BRRI}$ dhan29, $\mathrm{V}_{3}=\mathrm{BRRI}$ dhan74; $\mathrm{W}_{0}=$ No weeding, $\mathrm{W}_{1}=$ Two hand weeding at 15 and 35 DAT, $\mathrm{W}_{2}=$ Application of pre-emergence herbicide Commit, $\mathrm{W}_{3}=$ Application of early post-emergence herbicide Pediplus, $\mathrm{W}_{4}$ $=$ Application of pre-emergence herbicide Commit followed by early post-emergence herbicide Pediplus, $\mathrm{W}_{5}=\mathrm{Application}$ of pre-emergence herbicide Commit followed by one hand weeding at $35 \mathrm{DAT}, \mathrm{W}_{6}=$ Application of early post-emergence herbicide Pediplus followed by one hand weeding at 35 DAT

\section{Effect on yield and yield contributing characters of rice}

Effect of cultivar

Cultivar exerted significant effect on all the yield and yield contributing characters except length of panicle of Boro rice (Table 3$)$. The tallest plant $(86.59 \mathrm{~cm})$ was observed in the cultivar BRRI dhan29 and the shortest one was observed in BRRI dhan28 cultivar. Tyeb et al. (2013) observed similar variation in plant height due varietal differences. Varietal differences in plant height might be due to the heredity or varietal character. The highest number (11.81 and 9.50) of total and effective tillers hill ${ }^{1}$ was recorded in BRRI dhan 29 cultivar. The lowest number (10.10 and 7.50) of total and effective tillers hill ${ }^{-}$ ${ }^{1}$ was observed in BRRI dhan 28 cultivar. This might be due to the fact that BRRI dhan29 had the highest tiller production potentiality than other cultivars. This research finding corroborates the finding of Babikar (1986) who reported the variation of tiller production due to cultivars. The highest number (81.20) of grains panicle ${ }^{-1}$ and the lowest number (17.43) of sterile spikelets panicle ${ }^{-1}$ were observed in BRRI dhan 29 cultivar. On the other hand, the lowest number (76.82) of grains panicle ${ }^{-1}$ was recorded in BRRI dhan 28 cultivar. 1000-grain weight was the highest $(29.00 \mathrm{~g})$ in BRRI dhan 29 cultivar and the lowest (22.18 g) in BRRI dhan28 cultivar. The highest grain yield (5.17 $\mathrm{t} \mathrm{ha}^{-1}$ ) was recorded in BRRI dhan29 cultivar. This might be due to the fact of producing highest number of total and effective tillers hill $^{-1}$, highest number of grains panicle $^{-1}$, lowest number of sterile spikelets panicle ${ }^{-1}$ and heaviest 1000-grain weight of the cultivar BRRI dhan29. The lowest grain yield $\left(3.89 \mathrm{t} \mathrm{ha}^{-1}\right)$ was found in BRRI dhan28 cultivar due to lowest number of total and effective tillers hill ${ }^{-1}$, lowest number of grains panicle ${ }^{-1}$, highest number sterile spikelets panicle ${ }^{-1}$ and lightest 1000 -grain weight. Variation in grain yield due to cultivar was also reported by IRRI (1978), Alam (1988) and Sunyob et al. (2015). The highest straw yield $\left(5.80 \mathrm{t} \mathrm{ha}^{-1}\right)$ was found in BRRI dhan29 and the lowest one (4.99 $\mathrm{tha}^{-}$ $\left.{ }^{1}\right)$ was observed in BRRI dhan29 (Table 3). 
Table 3. Effect of cultivars on yield and yield contributing characters of Boro rice cultivars

\begin{tabular}{lccccccccc}
\hline Cultivars & $\begin{array}{c}\text { Plant } \\
\text { height } \\
(\mathrm{cm})\end{array}$ & $\begin{array}{c}\text { Total } \\
\text { tillers hill } \\
1 \text { (no. })\end{array}$ & $\begin{array}{c}\text { Effective } \\
\text { tillers hill } \\
(\text { no. })\end{array}$ & $\begin{array}{c}\text { Length of } \\
\text { panicle } \\
(\mathrm{cm})\end{array}$ & $\begin{array}{c}\text { Grains } \\
\text { panicle } \\
(\text { no. })\end{array}$ & $\begin{array}{c}\text { Sterile } \\
\text { spikelets } \\
\text { panicle }^{-1} \\
(\text { no. })\end{array}$ & $\begin{array}{c}\text { 1000-grain } \\
\text { weight }(\mathrm{g})\end{array}$ & $\begin{array}{c}\text { Grain } \\
\text { yield } \\
\left(\mathrm{t} \mathrm{ha}^{-1}\right)\end{array}$ & $\begin{array}{c}\text { Straw } \\
\text { yield } \\
\left(\mathrm{t} \mathrm{ha}^{-1}\right)\end{array}$ \\
\hline BRRI dhan28 & $80.50 \mathrm{c}^{*}$ & $10.10 \mathrm{c}$ & $7.500 \mathrm{c}$ & $20.69 \mathrm{~b}$ & $76.82 \mathrm{c}$ & $20.19 \mathrm{a}$ & $22.18 \mathrm{~b}$ & $3.890 \mathrm{c}$ & $4.990 \mathrm{c}$ \\
BRRI dhan29 & $86.59 \mathrm{a}$ & $11.81 \mathrm{a}$ & $9.500 \mathrm{a}$ & $22.26 \mathrm{a}$ & $81.20 \mathrm{a}$ & $17.43 \mathrm{c}$ & $29.00 \mathrm{a}$ & $5.167 \mathrm{a}$ & $5.801 \mathrm{a}$ \\
BRRI dhan74 & $84.34 \mathrm{~b}$ & $10.67 \mathrm{~b}$ & $8.133 \mathrm{~b}$ & $21.54 \mathrm{ab}$ & $78.82 \mathrm{~b}$ & $18.67 \mathrm{~b}$ & $22.63 \mathrm{~b}$ & $4.169 \mathrm{~b}$ & $5.337 \mathrm{~b}$ \\
\hline Level of sig. & 0.01 & 0.01 & 0.01 & 0.05 & 0.01 & 0.01 & 0.01 & 0.01 & 0.01 \\
CV $(\%)$ & 2.08 & 2.37 & 6.12 & 5.09 & 2.72 & 4.54 & 8.41 & 4.76 & 4.40 \\
\hline
\end{tabular}

*In a column, figures with same letter (s) or without letter do not differ significantly whereas figures with dissimilar letter differ significantly (as per DMRT).

Table 4. Effect of methods of weeding on yield and yield contributing characters of Boro rice cultivars

\begin{tabular}{lccccccccc}
\hline $\begin{array}{l}\text { Methods } \\
\text { of } \\
\text { weeding }\end{array}$ & $\begin{array}{c}\text { Plant } \\
\text { height } \\
(\mathrm{cm})\end{array}$ & $\begin{array}{c}\text { Total tillers } \\
\text { hill }^{-1} \\
(\text { no. })\end{array}$ & $\begin{array}{c}\text { Effective } \\
\text { tillers hill }^{-1} \\
(\text { no. })\end{array}$ & $\begin{array}{c}\text { Panicle } \\
\text { length } \\
(\mathrm{cm})\end{array}$ & $\begin{array}{c}\text { Grains } \\
\text { panicle }^{-1} \\
(\text { no. })\end{array}$ & $\begin{array}{c}\text { Sterile spikelets } \\
\text { panicle }^{-1} \\
(\text { no. })\end{array}$ & $\begin{array}{c}\text { 1000- grain } \\
\text { weight }(\mathrm{g})\end{array}$ & $\begin{array}{c}\text { Grain } \\
\text { yield } \\
\left(\mathrm{t} \mathrm{ha}^{-1}\right)\end{array}$ & $\begin{array}{c}\text { Straw } \\
\text { yield } \\
\left(\mathrm{t} \mathrm{ha}^{-1}\right)\end{array}$ \\
\hline $\mathrm{W}_{0}$ & $80.59 \mathrm{~b} *$ & $9.556 \mathrm{e}$ & $6.72 \mathrm{f}$ & $19.89 \mathrm{e}$ & $76.06 \mathrm{c}$ & $22.11 \mathrm{a}$ & $22.95 \mathrm{c}$ & $1.92 \mathrm{f}$ & $3.06 \mathrm{f}$ \\
$\mathrm{W}_{1}$ & $81.21 \mathrm{~b}$ & $10.22 \mathrm{~d}$ & $7.39 \mathrm{e}$ & $20.31 \mathrm{de}$ & $76.49 \mathrm{c}$ & $20.89 \mathrm{~b}$ & $23.57 \mathrm{bc}$ & $3.88 \mathrm{e}$ & $4.83 \mathrm{e}$ \\
$\mathrm{W}_{2}$ & $81.62 \mathrm{~b}$ & $10.33 \mathrm{~d}$ & $7.67 \mathrm{e}$ & $20.71 \mathrm{~cd}$ & $76.97 \mathrm{c}$ & $20.22 \mathrm{~b}$ & $23.87 \mathrm{bc}$ & $4.50 \mathrm{~d}$ & $5.31 \mathrm{~d}$ \\
$\mathrm{~W}_{3}$ & $83.08 \mathrm{~b}$ & $10.89 \mathrm{c}$ & $8.48 \mathrm{~d}$ & $21.03 \mathrm{~cd}$ & $78.44 \mathrm{bc}$ & $18.11 \mathrm{c}$ & $24.64 \mathrm{abc}$ & $4.88 \mathrm{c}$ & $5.71 \mathrm{c}$ \\
$\mathrm{W}_{4}$ & $83.64 \mathrm{~b}$ & $11.34 \mathrm{~b}$ & $8.83 \mathrm{c}$ & $21.27 \mathrm{c}$ & $79.62 \mathrm{abc}$ & $17.44 \mathrm{~cd}$ & $25.08 \mathrm{abc}$ & $5.05 \mathrm{bc}$ & $6.08 \mathrm{~b}$ \\
$\mathrm{~W}_{5}$ & $89.62 \mathrm{a}$ & $12.22 \mathrm{a}$ & $10.33 \mathrm{a}$ & $24.31 \mathrm{a}$ & $83.05 \mathrm{a}$ & $15.89 \mathrm{e}$ & $26.62 \mathrm{a}$ & $5.45 \mathrm{a}$ & $6.38 \mathrm{a}$ \\
$\mathrm{W}_{6}$ & $86.90 \mathrm{a}$ & $11.45 \mathrm{~b}$ & $9.22 \mathrm{~b}$ & $22.98 \mathrm{~b}$ & $81.97 \mathrm{ab}$ & $16.67 \mathrm{de}$ & $25.50 \mathrm{ab}$ & $5.18 \mathrm{~b}$ & $6.25 \mathrm{a}$ \\
\hline Sig. lev. & 0.01 & 0.01 & 0.01 & 0.01 & 0.01 & 0.01 & 0.05 & 0.01 & 0.01 \\
CV $(\%)$ & 2.08 & 2.37 & 6.12 & 24.13 & 5.09 & 2.72 & 4.54 & 8.41 & 4.76 \\
\hline
\end{tabular}

*In a column, figures with same letter (s) or without letter do not differ significantly whereas figures with dissimilar letter differ significantly; $\mathrm{W}_{0}=$ No weeding, $\mathrm{W}_{1}=$ Two hand weeding at 15 and 35 DAT, $\mathrm{W}_{2}=$ Application of pre-emergence herbicide Commit, $\mathrm{W}_{3}=$ Application of early post-emergence herbicide Pediplus, $\mathrm{W}_{4}=$ Application of pre-emergence herbicide Commit followed by early post-emergence herbicide Pediplus, $\mathrm{W}_{5}=$ Application of pre-emergence herbicide Commit followed by one hand weeding at 35 DAT, $W_{6}=$ Application of early post-emergence herbicide Pediplus followed by one hand weeding at 35 DAT

\section{Effect of weeding regime}

All the yield and yield contributing characters of boro rice were significantly affected by weeding regime (Table 4). The tallest plant $(89.62 \mathrm{~cm})$ was found in $\mathrm{W}_{6}$ (application of early post-emergence herbicide Acetachlor + Bensufuron methyl followed by one hand weeding at 35 DAT) treatment which was statistically identical with $\mathrm{W}_{6}$ (application of early post-emergence herbicide Acetachlor + Bensufuron methyl followed by one hand weeding at 35 DAT) treatment. The shortest plant (80.59 $\mathrm{cm}$ ) was found in $\mathrm{W}_{0}$ (No weeding) treatment which was nearly similar with $\mathrm{W}_{1}$ (Two hand weedings at 15 and 35 DATs) and $\mathrm{W}_{2}$ (Application of pre-emergence herbicide Pretilachlor) treatments. Weed competition was severe in no weeding condition and thus plant height in rice was reduced. On the other hand, application of early post emergence herbicide or pre-emergence herbicide followed by one hand weeding at 35 DAT treatment through the crop growth period, competition of weeds with crop plant was less therefore, plant height increased. The highest number (12.22 and 10.33) of total and effective tillers hill ${ }^{-1}$ was observed in $\mathrm{W}_{5}$ (Application of pre-emergence herbicide Pretilachlor followed by one hand weeding at 35 DAT) treatment. The lowest number (9.55 and 6.72) of total and effective tillers hill ${ }^{-1}$ was observed in $\mathrm{W}_{0}$ (No weeding) treatment. In no weeding treatment weed crop competition was higher and weed suppressed the rice plant growth ultimately tiller production was reduced (Table 3 ). The longest panicle $(24.31 \mathrm{~cm})$ was observed in $\mathrm{W}_{5}$ (application of preemergence herbicide Commit followed by one hand weeding at 35 DAT) treatment and the smallest one $\left(19.89 \mathrm{~cm}\right.$ ) was observed in $\mathrm{W}_{0}$ (No weeding) treatment. Application of pre-emergence herbicide Pretilachlor followed by one hand weeding at 35 DAT produced the highest number (83.05) of grains panicle ${ }^{-1}$ while the lowest number (76.06) of grains panicle ${ }^{-1}$ was observed in no weeding treatment. In this study, application of preemergence herbicide Pretilachlor followed by one hand weeding at 35 DAT produced the highest number of grains panicle $^{-1}$ which might be attributed due to vigorous growth of rice plant because of less competition of crop plants with weed. The highest number (22.11) of sterile spikelets panicle ${ }^{-1}$ was observed in $\mathrm{W}_{0}$ (No weeding) treatment, while the lowest number (15.89) of grains panicle $^{-1}$ was observed in $\mathrm{W}_{5}$ (application of preemergence herbicide Pretilachlor followed by one hand weeding at 35 DAT) treatment. The highest 1000-grain weight $\left(26.62 \mathrm{~g}\right.$ ) was recorded in $\mathrm{W}_{5}$ (application of preemergence herbicide Pretilachlor followed by one hand weeding at 35 DAT) treatment, while the lowest 1000grain weight (22.95 g) was recorded in $\mathrm{W}_{0}$ (No weeding) treatment. The highest grain yield $\left(5.45 \mathrm{t} \mathrm{ha}^{-1}\right)$ was recorded in $\mathrm{W}_{5}$ (application of pre-emergence herbicide Pretilachlor followed by one hand weeding at 35 DAT) 
treatment followed by $\mathrm{W}_{6}$ (Application of early postemergence herbicide Acetachlor + Bensufuron methyl followed by one hand weeding at 35 DAT) $\left(5.18 \mathrm{t} \mathrm{ha}^{-1}\right)$ treatment, while the lowest grain yield $\left(1.92 \mathrm{t} \mathrm{ha}^{-1}\right)$ was observed in $\mathrm{W}_{0}$ (No weeding) treatment (Table 4). The weeds compete with the crop for nutrient, water, air, sunlight and space in no weeding treatment and reduced the grain yield of rice. The increased yield was contributed in $\mathrm{W}_{5}$ (Application of pre-emergence herbicide Pretilachlor followed by one hand weeding at 35 DAT) treatment by higher number of effective tiller hill $^{-1}$, higher number of grains pancicle ${ }^{-1}$ and heaviest 1000-grain weight over no weeding treatment. These might be due to the fact that the different weeding regime treatments reduced the weed crop competition and soil was well aerated which facilitated the crop for absorption of greater amount of plant nutrients, moisture and greater reception of solar radiation for better growth. Straw yield was significantly influenced by different weeding regimes (Table 4). The highest straw yield $\left(6.38 \mathrm{t} \mathrm{ha}^{-1}\right)$ was observed in $\mathrm{W}_{5}$ (application of pre-emergence herbicide Pretilachlor followed by one hand weeding at 35 DAT) treatment which was statistically identical with $\mathrm{W}_{6}$ (application of early post-emergence herbicide Acetachlor + Bensufuron methyl followed by one hand weeding at $35 \mathrm{DAT})\left(6.25 \mathrm{t} \mathrm{ha}^{-1}\right)$ treatment, while the lowest straw yield $\left(3.06 \mathrm{t} \mathrm{ha}^{-1}\right)$ was observed in $\mathrm{W}_{0}$ (No weeding) (Table 4).

Table 5. Interaction effect of variety and methods of weeding on yield and yield contributing characters of Boro rice

\begin{tabular}{|c|c|c|c|c|c|c|c|c|c|c|}
\hline $\begin{array}{l}\text { Interaction } \\
\text { (Cultivar } \times \\
\text { weeding } \\
\text { regime) } \\
\end{array}$ & $\begin{array}{l}\text { Plant } \\
\text { height } \\
(\mathrm{cm})\end{array}$ & $\begin{array}{c}\text { Total tillers } \\
\text { hill }^{-1} \\
\text { (no.) }\end{array}$ & $\begin{array}{l}\text { Effective } \\
\text { tillers hill }{ }^{-1} \\
\text { (no.) }\end{array}$ & $\begin{array}{l}\text { Length } \\
\text { of } \\
\text { panicle } \\
(\mathrm{cm}) \\
\end{array}$ & $\begin{array}{c}\text { Grains } \\
\text { panicle }^{-1} \\
\text { (no.) }\end{array}$ & $\begin{array}{c}\text { Sterile } \\
\text { spikelets } \\
\text { panicle }^{-1} \\
\text { (no.) }\end{array}$ & $\begin{array}{c}1000- \\
\text { grain } \\
\text { weight } \\
(\mathrm{g})\end{array}$ & $\begin{array}{c}\text { Grain } \\
\text { yield } \\
\left(\mathrm{t} \mathrm{ha}^{-1}\right)\end{array}$ & $\begin{array}{c}\text { Straw } \\
\text { yield } \\
\left(\mathrm{t} \mathrm{ha}^{-1}\right)\end{array}$ & $\begin{array}{c}\text { Net } \\
\text { income } \\
(\mathrm{Tk} .)\end{array}$ \\
\hline $\mathrm{V}_{1} \mathrm{~W}_{0}$ & 77.70 & $8.66 h^{*}$ & $5.66 \mathrm{j} j$ & $19.05 \mathrm{~g}$ & 75.48 & 23.33 & 20.67 & $1.83 \mathrm{j}$ & $2.83 \mathrm{j}$ & -21490 \\
\hline $\mathrm{V}_{1} \mathrm{~W}_{1}$ & 78.70 & $9.67 \mathrm{fg}$ & 6.66hi & $19.86 \mathrm{fg}$ & 75.69 & 23.00 & 21.11 & $3.11 \mathrm{i}$ & $4.13 \mathrm{~h}$ & 9960 \\
\hline $\mathrm{V}_{1} \mathrm{~W}_{2}$ & 79.30 & $9.67 \mathrm{fg}$ & 7.00ghi & $20.55 \mathrm{def}$ & 75.72 & 22.67 & 21.20 & $3.91 \mathrm{~h}$ & $5.00 \mathrm{~g}$ & 19650 \\
\hline $\mathrm{V}_{1} \mathrm{~W}_{3}$ & 81.21 & $10.00 \mathrm{ef}$ & 7.50efg & $20.84 c-f$ & 75.72 & 19.00 & 22.40 & $4.13 \mathrm{~h}$ & $5.28 \mathrm{~g}$ & 33890 \\
\hline $\mathrm{V}_{1} \mathrm{~W}_{4}$ & 81.70 & $10.67 \mathrm{cde}$ & $8.00 \mathrm{de}$ & $20.95 c-f$ & 77.12 & 18.33 & 22.53 & 4.57efg & 5.84def & 37070 \\
\hline $\mathrm{V}_{1} \mathrm{~W}_{5}$ & 82.70 & $11.33 \mathrm{c}$ & $9.33 b$ & $21.86 \mathrm{~cd}$ & 80.13 & 17.33 & 24.37 & $4.99 \mathrm{~d}$ & $5.94 c-f$ & 50880 \\
\hline $\mathrm{V}_{1} \mathrm{~W}_{6}$ & 82.17 & $10.67 \mathrm{cde}$ & $8.33 \mathrm{~cd}$ & $21.75 \mathrm{cdc}$ & 77.86 & 17.67 & 23.00 & 4.68def & $5.91 \mathrm{c}-\mathrm{f}$ & 28370 \\
\hline $\mathrm{V}_{2} \mathrm{~W}_{0}$ & 82.33 & $10.67 \mathrm{de}$ & $8.00 \mathrm{de}$ & $20.35 \mathrm{efg}$ & 76.95 & 20.00 & 26.47 & $2.07 \mathrm{j}$ & $3.35 \mathrm{i}$ & -12300 \\
\hline $\mathrm{V}_{2} \mathrm{~W}_{1}$ & 83.04 & $11.00 \mathrm{~cd}$ & $8.33 \mathrm{~cd}$ & $20.57 \mathrm{def}$ & 77.62 & 19.00 & 27.80 & $4.55 \mathrm{fg}$ & $5.23 \mathrm{~g}$ & 22140 \\
\hline $\mathrm{V}_{2} \mathrm{~W}_{2}$ & 83.31 & $11.00 \mathrm{~cd}$ & $8.33 \mathrm{~cd}$ & $20.83 c-f$ & 78.89 & 18.67 & 28.13 & $5.36 \mathrm{c}$ & $5.74 \mathrm{ef}$ & 55870 \\
\hline $\mathrm{V}_{2} \mathrm{~W}_{3}$ & 84.60 & $12.00 \mathrm{~b}$ & $9.66 b$ & $21.26 \mathrm{c}-\mathrm{f}$ & 80.61 & 17.00 & 29.07 & $5.91 b$ & $6.150 b c$ & 67850 \\
\hline $\mathrm{V}_{2} \mathrm{~W}_{4}$ & 85.65 & $12.67 \mathrm{a}$ & $10.50 \mathrm{a}$ & $21.57 \mathrm{cde}$ & 81.92 & 16.33 & 30.19 & $5.95 b$ & $6.390 \mathrm{~b}$ & 72100 \\
\hline $\mathrm{V}_{2} \mathrm{xW}_{5}$ & 94.30 & $12.67 \mathrm{a}$ & $11.00 \mathrm{a}$ & $26.33 \mathrm{a}$ & 86.31 & 15.00 & 30.97 & $6.37 \mathrm{a}$ & $7.000 \mathrm{a}$ & 76000 \\
\hline $\mathrm{V}_{2} \mathrm{~W}_{6}$ & 92.91 & $12.67 \mathrm{a}$ & $10.67 \mathrm{a}$ & $24.96 \mathrm{~b}$ & 86.09 & 16.00 & 30.37 & $5.96 \mathrm{~b}$ & $6.750 \mathrm{a}$ & 57620 \\
\hline $\mathrm{V}_{3} \mathrm{~W}_{0}$ & 81.73 & $9.33 \mathrm{~g}$ & $6.50 \mathrm{i}$ & 20.27efg & 75.74 & 23.00 & 21.72 & $1.87 \mathrm{j}$ & $3.00 \mathrm{j}$ & -17350 \\
\hline $\mathrm{V}_{3} \mathrm{~W}_{1}$ & 81.90 & 10.00ef & $7.16 \mathrm{fgh}$ & 20.50def & 76.17 & 20.67 & 21.80 & $3.99 \mathrm{~h}$ & $5.12 \mathrm{~g}$ & 10610 \\
\hline $\mathrm{V}_{3} \mathrm{~W}_{2}$ & 82.27 & $10.33 \mathrm{de}$ & 7.66ef & 20.74def & 76.30 & 19.33 & 22.27 & $4.23 \mathrm{gh}$ & $5.20 \mathrm{~g}$ & 31650 \\
\hline $\mathrm{V}_{3} \mathrm{~W}_{3}$ & 83.43 & $10.67 \mathrm{cde}$ & $8.26 \mathrm{~cd}$ & $20.98 c-f$ & 78.99 & 18.33 & 22.44 & $4.59 \mathrm{~d}-\mathrm{g}$ & $5.71 \mathrm{f}$ & 37680 \\
\hline $\mathrm{V}_{3} \mathrm{~W}_{4}$ & 83.58 & $10.67 \mathrm{cde}$ & $8.00 \mathrm{de}$ & $21.28 \mathrm{c}-\mathrm{f}$ & 79.83 & 17.67 & 22.53 & 4.64def & $6.02 \mathrm{cde}$ & 38670 \\
\hline $\mathrm{V}_{3} \mathrm{~W}_{5}$ & 91.87 & $12.67 \mathrm{a}$ & $10.67 \mathrm{a}$ & $24.75 b$ & 82.73 & 15.33 & 24.51 & $4.98 \mathrm{cde}$ & $6.21 b c$ & 50450 \\
\hline $\mathrm{V}_{3} \mathrm{~W}_{6}$ & 85.63 & $11.00 \mathrm{~cd}$ & $8.667 \mathrm{c}$ & $22.24 \mathrm{c}$ & 81.96 & 16.33 & 23.12 & 4.88def & $6.10 \mathrm{~cd}$ & 24290 \\
\hline Level of sig. & $\mathrm{NS}$ & 0.01 & 0.01 & 0.01 & NS & NS & NS & 0.01 & 0.01 & \\
\hline CV $(\%)$ & 4.00 & 3.28 & 3.62 & 3.51 & 4.47 & 6.51 & 9.26 & 5.02 & 3.00 & \\
\hline
\end{tabular}

*In a column, figures with same letter (s) or without letter do not differ significantly whereas figures with dissimilar letter differ significantly (as per DMRT).

$\mathrm{V}_{1}=\mathrm{BRRI}$ dhan28, $\mathrm{V}_{2}=\mathrm{BRRI}$ dhan29, $\mathrm{V}_{3}=\mathrm{BRRI}$ dhan74

$\mathrm{W}_{0}=$ No weeding, $\mathrm{W}_{1}=$ Two hand weeding at 15 and 35 DAT, $\mathrm{W}_{2}=$ Application of pre-emergence herbicide Commit, $\mathrm{W}_{3}=$ Application of early post-emergence herbicide Pediplus, $W_{4}=$ Application of pre-emergence herbicide Commit followed by early post-emergence herbicide Pediplus, $\mathrm{W}_{5}=$ Application of pre-emergence herbicide Commit followed by one hand weeding at 35 DAT, W6 = Application of early post-emergence herbicide Pediplus followed by one hand weeding at 35 DAT.

Interaction effect of cultivar and weeding regime

Interaction of cultivar and weeding regime exerted significant effect on total and effective tillers hill ${ }^{-1}$, length of panicle, grain yield and straw yield of and nonsignificant effect on plant height, grains panicle, sterile spikelets panicle ${ }^{-1}$ and 1000-grain weight (Table 5). The highest number of (12.67) total tillers hill ${ }^{-1}$ was produced by BRRI dhan29 in $\mathrm{W}_{5}$ (application of pre-emergence herbicide Pretilachlor followed by one hand weeding at 35 DAT) treatment. Treatments $\mathrm{W}_{4}$ (application of preemergence herbicide Pretilachlor followed by early postemergence herbicide Acetachlor + Bensufuron methyl), $\mathrm{W}_{6}$ (application of early post-emergence herbicide Acetachlor + Bensufuron methyl followed by one hand weeding at 35 DAT) in BRRI dhan29 and treatment $\mathrm{W}_{5}$ 
(application of pre-emergence herbicide Pretilachlor followed by one hand weeding at 35 DAT) in BRRI dhan74 were statistically identical. The lowest number total tillers hill-1 (8.66) was produced by BRRI dhan 28 in $\mathrm{W}_{0}$ (No weeding) treatment. The highest number (11.00) of effective tillers hill ${ }^{-1}$ was produced by BRRI dhan 29 in $\mathrm{W}_{5}$ (application of pre-emergence herbicide Pretilachlor followed by one hand weeding at 35 DAT) treatment. Treatments $\mathrm{W}_{4}$ (application of pre-emergence herbicide Pretilachlor followed by early post-emergence herbicide Acetachlor + Bensufuron methyl), $\mathrm{W}_{6}$ (application of early post-emergence herbicide Acetachlor + Bensufuron methyl followed by one hand weeding at 35 DAT) in BRRI dhan29 and treatment $\mathrm{W}_{5}$ (application of preemergence herbicide Pretilachlor followed by one hand weeding at 35 DAT) in BRRI dhan74 were statistically identical. The lowest effective tillers hill ${ }^{-1}$ (5.66) was produced by BRRI dhan 28 in $\mathrm{W}_{0}$ (No weeding) treatment. The longest panicle $(26.33 \mathrm{~cm})$ was produced by BRRI dhan29 in $\mathrm{W}_{5}$ (Application of pre-emergence herbicide Pretilachlor followed by one hand weeding at 35 DAT) treatment and the smallest one $(19.05 \mathrm{~cm})$ was produced by BRRI dhan 28 in $\mathrm{W}_{0}$ (No weeding) treatment (Table 5). Numerically the highest number (86.31) of grains panicle-

1 was produced with the cultivar BRRI dhan29 $\times$ application of pre-emergence herbicide

Pretilachlor followed by one hand weeding at 35 DAT. The highest grain yield $\left(6.37 \mathrm{t} \mathrm{ha}^{-1}\right)$ was produced by BRRI dhan29 in $\mathrm{W}_{5}$ (Application of pre-emergence herbicide Pretilachlor followed by one hand weeding at 35 DAT) treatment. Treatments $\mathrm{V}_{2} \mathrm{~W}_{3}$ (BRRI dhan $29 \times$ Application of early post-emergence herbicide Acetachlor + Bensufuron methyl), $\mathrm{V}_{2} \mathrm{~W}_{4}$ (BRRI dhan29 $\times$ application of pre-emergence herbicide Pretilachlor followed by early post-emergence herbicide (Acetachlor + Bensufuron methyl) and $\mathrm{V}_{2} \mathrm{~W}_{6}$ (BRRI dhan29 $\times$ pplication of early post-emergence herbicide Acetachlor + Bensufuron methyl followed by one hand weeding at 35 DAT) were statistically identical (Table 5). The integrated approach like herbicide followed by hand weeding performed better than herbicide or hand weeding alone, such as Application of pre-emergence herbicide Pretilachlor followed by one hand weeding at 35 DAT. The lowest grain yield $\left(1.83 \mathrm{t} \mathrm{ha}^{-1}\right)$ was produced by $\mathrm{V}_{1} \mathrm{~W}_{0}$ (BRRI dhan28 $\times$ No weeding), which was followed by $\mathrm{V}_{3} \mathrm{~W}_{0}(\mathrm{BRRI}$ dhan $74 \times$ No weeding) $(1.87 \mathrm{t}$ $\left.\mathrm{ha}^{-1}\right)$. The lowest grain yield $\mathrm{ha}^{-1}$ in the no weeding practices might be due to the poor performance of yield contributing characters like number of tillers hill ${ }^{-1}$ and grains panicle ${ }^{-1}$. Because of severe weed infestation occurred in the plots due to competition for moisture, nutrients between weed and rice plants. Similar research findings were also reported by Gogoi et al. (2000) and Attalla and Kholosy (2002). Straw yield was significantly influenced by different cultivars and weeding regimes. The highest straw yield $\left(7.00 \mathrm{t} \mathrm{ha}^{-1}\right)$ was produced by BRRI dhan29 in $\mathrm{W}_{5}$ (Application of pre-emergence herbicide Pretilachlor followed by one hand weeding at
35 DAT) treatment which was statistically identical with $\mathrm{V}_{2} \mathrm{~W}_{6}$ (BRRI dhan29 $\times$ Application of early postemergence herbicide Acetachlor + Bensufuron methyl followed by one hand weeding at 35 DAT).The lowest straw yield $\left(2.83 \mathrm{t} \mathrm{ha}^{-1}\right)$ was produced by $\mathrm{V}_{1} \mathrm{~W}_{0}$ (BRRI dhan $28 \times$ No weeding) which was followed by $\mathrm{V}_{3} \mathrm{~W}_{0}$ $\left(\right.$ BRRI dhan74 $\times$ No weeding) $\left(3.00 \mathrm{t} \mathrm{ha}^{-1}\right)$ treatment (Table 5).

\section{Economics of different weeding regime treatments}

In case of no weeding, there was no involvement of cost for weed control. It could be seen from Table 5 that the application of pre-emergence herbicide Commit followed by one hand weeding at 35 DAT $\left(\mathrm{W}_{5}\right)$ maximized (Tk. $76000 \mathrm{ha}^{-1}$ ) the net income and the second highest (Tk. $72100 \mathrm{ha}^{-1}$ ) net income was obtained from the application of pre-emergence herbicide Pretilachlor followed by early post-emergence herbicide Acetachlor + Bensufuron methyl $\left(\mathrm{W}_{4}\right)$ in BRRI dhan29. From this experiment, it is observed that application of pre-emergence herbicide Pretilachlor followed by one hand weeding at $35 \mathrm{DAT}$ maximized the highest net return in BRRI dhan29 yield increase in Boro rice.

\section{Conclusion}

From the present study it is observed that weeding treatment pre-emergence herbicide Pretilachlor followed by one hand weeding at 35 DAT produced the highest grain yield and highest net return. Therefore, it may be concluded that application of pre-emergence herbicide Pretilachlor followed by one hand weeding at 35 DAT might be the best treatment for controlling weed effectively as well as obtaining highest net income in BRRI dhan29. But further studies are needed in different locations to draw a concrete conclusion.

\section{References}

Ahmed G. J. U., Bhuiyan, M. K. A., Riches, C. R., Mortimer, M. and Jhonson, D. 2005. Farmer's participatory studies of integrated weed management system for intensified lowland. Journal of Agronomy, 31- 32 .

Alam, A.B.M.M. 1988. Performance of local and modern varieties of boro rice under irrigated condition. In: Research Activities 1986-87. Farming System Research and Development Programme. Bangladesh Agricultural University, Mymensingh. pp. 24-27.

Attalla, S. I. and Kholosy, A. S. 2002: Effect of weed control treatments transplanted rice. Faculty of Agriculture, Cairo University, 53(4): 531-538.

Babiker, F. S. H. 1986. The effect of zinc sulphate levels on rice growth and productivity. Alexandria Journal of Agricultural Research, 31(2): 480-481.

Bari, M. N. 2010. Effect of herbicides on weed suppression and rice yield in transplanted wetland rice. Pakistan Journal of Weed Science and Research, 16(4): 349-361.

Bari, M. N., Mamun, A. A. and Anwar, S. M. S. 1995. Weed infestation in transplanted aman rice as affected by land topography and time of transplanting. Bangladesh Journal of Agricultural Science, 22(2): 227-235.

BBS (Bangladesh Bureau of Statistics). 2016. Monthly Statistical Bulletin, Ministry of Planning. Government of the People's 
Republic of Bangladesh. Dhaka. pp. 68-69.

BBS (Bangladesh Bureau of Statistics) 2018. Statistical Yearbook of Bangladesh. Statistics Division, Ministry of Planning. Govt. Peoples' Republic of Bangladesh. p. 143

Cruz, E. D., Moody, K. and Ramos, M. B. D. 1986. Reducing variability sampling weeds in upland rice (Oryza sativa). Philippine Journal of Weed Science, 13: 56-59

Gogoi, A. K., Rajkhona, D. J. and Kandali, R. 2000. Effect of variety and weed control practices on rice productivity and weed growth. Indian Journal of Agronomy, 45(3): 580-585.

Gomez, K. A. and Gomez, A. A. 1984. Statistical procedures for Agricultural Research. John wiley and sons. New York, Chichester, Brisbane, Toronto. pp. 207-215.

Hoque, M. H., Hossain, M. M., Khan, M. R. H., Khalequzzaman, K. M. and Karim, S. M. R. 2003. Effect of varieties of rice and weeding on weed growth and yield of transplant aman rice. Asian Journal of Plant Sciences, 2(13): 993-998. https://doi.org/10.3923/ajps.2003.993.998

Hussain, M. M., Alam, M. S., Islam, M. A., Rashid, M. M., Islam, M. F., Rashid, M. A., Razzaque, M. S., Mamin, M. S. I., Islam, M. R., Kabir, H., Parvin, S. and Mukul, H. R. 2006. In: Baqui, M.A. (eds.). In: Proc. Twenty First BRRI-DAE Joint Workshop. Bangladesh Rice Research Institute Joydebpur, Gazipur, Bangladesh September 19-21. pp. 1-3.

IRRI (International Rice Research Institute). 1978. Annual Report. Intl. Rice Res. Inst., Los Banos, Laguna, Philippines. pp. 1- 8.

Mamun, A.A., Karim, S.M.R., Begum, M., Uddin, M.I. and Rahman, M.A. 1993. Weed survey in different crops under three agro- ecological zones of Bangladesh. Bangladesh Agricultural University Research System, 8: 41- 51.

Prasad, K. Prasad, K. and Raffy, A. 1995. Effect of integrated weed management on weed growth nutrient uptake, economics and energetics in rainfed upland rice (Oryza sativa L.). Indian Journal of Agricultural Science, 65(4): 260- 264.

Sathyamoorthy, N. K., Mahendran, S., Babu, R. and Ragavan, T. 2004. Effect of integrated weed management practices on total weed dry weight, nutrient removal of weeds in rice-rice wet seedbed system. Journal of Agronomy, 3(4): 263-267. https://doi.org/10.3923/ja.2004.263.267

Sarker, P. A. 1979. Study on varietal response to planting geometry and in transplanted rice. Allahabad Farmer, 50(4): 357- 358.

Sunyob, N.B., Juraimi, A.S., Hakim, M.A., Man, A., Selamat, A. and Alam M.A., 2015. Competitive ability of some selected rice varieties against weed under aerobic condition. International Journal of Agriculture \& Biology, 17(1): 61-70.

Tyeb, A., Paul, S. K. and Samad, M. A. 2013. Performance of variety and spacing on the yield and yield contributing characters of transplanted aman rice. Journal of Agroforestry and Environment, 7(1): 57-60.

UNDP and FAO. 1988. Land Resources Appraisal of Bangladesh For Agricultural Development Report No. 2. Agro-ecological Regions of Bangladesh. United Nations Development Programme and Food and Agriculture Organization, Rome, Italy. pp. 212-221. 